July 2006

\title{
The Endless Debate over the 'G Word'
}

\author{
Major Brent Beardsley
}

Follow this and additional works at: https://digitalcommons.usf.edu/gsp

\section{Recommended Citation}

Beardsley, Major Brent (2006) "The Endless Debate over the 'G Word'," Genocide Studies and Prevention: An International Journal: Vol. 1: Iss. 1: Article 10.

Available at: https://digitalcommons.usf.edu/gsp/vol1/iss1/10

This Articles is brought to you for free and open access by the Open Access Journals at Digital Commons @ University of South Florida. It has been accepted for inclusion in Genocide Studies and Prevention: An International Journal by an authorized editor of Digital Commons @ University of South Florida. For more information, please contact digitalcommons@usf.edu. 


\title{
The Endless Debate over the 'G Word'
}

\author{
Major Brent Beardsley \\ Canadian Forces Leadership Institute, Royal Military College \\ of Canada
}

I am an infantry officer in the Canadian Army of the Canadian Armed Forces. In 1993-1994, I served as the personal staff officer to then Major-General Roméo Dallaire, the Force Commander of the United Nations Assistance Mission for Rwanda (UNAMIR). As such, I was a witness, a bystander, and an occasional rescuer and helper to what the Organization of African Unity labeled "the Preventable Genocide."

One of the major reasons the genocide in Rwanda was not prevented or stopped was the endless debate in April, May, and June 1994, when the majority of attention and effort was focused on debating whether or not genocide was taking place in Rwanda instead of on preparing and conducting a multi-disciplinary (including military) intervention to stop the killing. For days, weeks, and months the discussions went back and forth between those who labeled the catastrophe a genocide, and demanded that the international community live up to its obligations under the UN Convention on the Prevention and Punishment of the Crime of Genocide (UNCG) and intervene to suppress the genocide, and those who argued that the situation in Rwanda was not a genocide but "just gross violations of human rights, crimes against humanity and war crimes" (as if these were acceptable crimes to ignore). The failure to intervene permitted the genocide to largely run its course, consuming between 500,000 and 1 million innocent men, women, and children.

On too many occasions, especially during the genocide in Rwanda and the current genocide in Darfur, the organs of the international community have been far more focused on conducting some form of academic or legal debate over the use of the word "genocide" to describe these catastrophes than on focusing our attention and efforts toward actually doing something to stop the killing. Never were we more frustrated and saddened in Rwanda during the genocide than when we were informed on a Friday that the Security Council had adjourned for the weekend, without decision. We knew that while the diplomats and bureaucrats would be enjoying the culinary delights of Manhattan, another 10,000 to 20,000 innocent men, women, and children would die while the world discussed, debated, contemplated, and, inevitably, let the genocide run its course. While the determination of genocide is not a matter to be taken lightly, it must also not become an excuse to procrastinate while thousands are dying.

As a witness to the events of 1994, I have had to live with the failure of the international community to identify the catastrophic killings in Rwanda as genocide in a sufficient matter of time in order to intervene to stop the killing and save Rwandan lives. I have also had to live with my own role as a member of UNAMIR for our failure, for my failure, to prevent or stop the genocide. I do not wish to see the same mistake made again, and, therefore, I appreciate the opportunity the editors of this new professional journal have given me to presenting this opinion piece on the current situation in Darfur. I do not claim to be a genocide scholar or an expert in anything other than my chosen profession, and I do not consider my opinions any more valid

Major Brent Beardsley, "The Endless Debate over the 'G Word'." Genocide Studies and Prevention 1, 1 (July 2006): 79-82. (C) 2006 Genocide Studies and Prevention. 
than others'. I approach this topic with the experience of a witness to a genocide, and a witness to the failure of humanity to stop the Rwandan genocide; I only wish to offer some ideas, which I hope will spark a far greater debate among better men and women than I and a greater effort in developing a more effective response to the ongoing genocide in Darfur.

In 2004, on the tenth anniversary of the Rwandan genocide, leaders from across the world or their representatives, scholars, activists, and survivors gathered in Kigali, Rwanda, to commemorate the genocide and lament the failure of humanity and the international community to prevent or stop it in 1994. The sacred, yet hollow, words "Never Again" were echoed by virtually every speaker, and vague and false assurances and commitments were made, declaring that such a failure must never happen again. As too many spoke these shallow words, a few thousand kilometers north of Rwanda, in the Darfur region of Sudan, the first reports were emerging in the Western media of a humanitarian catastrophe, clouded in a civil war or counter-insurgency campaign, which had at that time claimed the lives of at least 30,000 civilians, forced at least 200,000 into exile as refugees, and displaced at least a million inside Darfur. Little, if anything, was said in Kigali of what was happening in Darfur, and the killings continued.

Since 2004 we have seen an US-sponsored investigation concluding that genocide is taking place in Darfur; a United Nations investigation concluding that genocide is not taking place in Darfur; sporadic, ill-informed media coverage; division within the diplomatic, non-governmental, and academic communities over the question of genocide in Darfur; and an endless debate that rapidly deteriorates into legal tailchasing and stale academic debates. All the while, Darfurians die, and the response to date by the United Nations, the European Union, the African Union (AU), and others has not stopped the killing, which is now conservatively estimated to have claimed the lives of more than 300,000 people and forcibly displaced over 2 million others. And the debate continues as people-innocent men, women, and children-die at a rate of almost 10,000 per month.

Is genocide taking place in Darfur? First, the UNCG states that genocide involves "the intent to destroy in whole or in part members of a national, ethnic, racial or religious group as such."1 The people of Darfur are black Africans with distinct tribal and ethnic affiliations, which are recognized as such by the perpetrators and fellow Darfurians. They, in fact, constitute members of specific ethnic and racial groups. Second, genocide is committed by "killing members of the group; causing serious bodily or mental harm to members of the group; deliberately inflicting on the group conditions of life calculated to bring about its physical destruction in whole or in part; imposing measures intended to prevent births within the group; [and/or] forcibly transferring children of the group to another group." 2 The Janjaweed militia has murdered tens of thousands of human beings in Darfur; subjected men to execution and women to gang rape and branding; separated men from women, thus preventing births; and abducted children, who allegedly are being sold into slavery. In addition, it has destroyed homes, wells, farms, and crops for the express purpose of making the area uninhabitable and thus forcing the population into camps within and outside Sudan. These camps are located in desert areas, with the most extreme weather conditions, and people must live without access to water, food, firewood, shelter, or medical support, in conditions of life that are very likely, over time, to result in death. Each of the above facts, well documented by international, governmental, nongovernmental, and media organizations, is an act of genocide; yet we continue to 
debate endlessly whether or not the "threshold of intent" has been met. When anyone starts killing people and the death rate rises in two years from zero to 300,000 dead, I would suggest, common sense should dictate that a genocidal intent is being clearly demonstrated.

Under the UNCG, the contracting parties "may call upon the competent organs of the United Nations take such action under the Charter of the United Nations as they consider appropriate for preventing and suppressing these acts of genocide."3 Therefore, if it can be concluded that genocide is taking place in Darfur, then the international community has a moral obligation to intervene to stop this latest genocide.

As the current situation in Darfur continues to develop, the catastrophe in the region has been labeled a genocide by the Bush administration, by numerous genocide scholars, by large parts of the media, and by non-governmental organizations such as Genocide Watch. To date, efforts to respond to the genocide have been limited to ineffectual diplomacy with the Sudanese government in Khartoum; the deployment of a weakly mandated and inadequately led, trained, equipped, and supported AU peacekeeping force; and the provision of money, humanitarian aid, and some cast-off equipment. The international community is slowly coming to the conclusion that the lack of will and means to respond effectively to the situation in Darfur is in fact permitting another genocide to unfold on the African continent, regardless of the pontificating statements of 2004 in Kigali, when all present committed to "Never Again."

What will be required to stop the genocide in Darfur? First, an honest and common-sense admission that genocide is taking place there. Second, an honest admission that we, in the international community, especially those of us in the West, have a moral obligation to intervene to stop that genocide. Third, doing just that: threatening, while preparing a full humanitarian intervention, and, if the government of Sudan does not stop the killing in Darfur, actually intervening with the full military might of the international community to force the government of Sudan to stand down its armed forces, police, and militia or risk losing some or all of these forces. The armed forces of Sudan are all that keep the current regime in power. If it were to lose its military capability, the regime's survival would be at an end.

The endless debate over the "G-word" and the totally inadequate response to the genocide in Darfur have not to date stopped, and will not stop, the killing. We should not be surprised. For forty years, regimes in Khartoum have employed genocide as a tool in their ethnic, racial, and religious consolidation of power. For twenty years, African Christians in the south of Sudan were subjected to genocidal violence. In the 1980s, the Dinka people were almost exterminated. In the 1990s, the Nuba people were almost exterminated in yet another genocide. Successive governments of Sudan, with virtual immunity, have repeatedly resorted to genocide as a matter of domestic policy that has claimed the lives of up to 2 million of their citizens.

It is unlikely that the government of Sudan will change its behavior until it believes that, this time, the international community is serious and recognizes that it has more to lose than to gain by continuing a policy of genocide in Darfur.

Every problem is not a nail that can be solved by using a hammer. But some problems are nails that do require the use of a hammer. The genocide in Darfur is such a situation, and, despite our best efforts-or our worst efforts, or no effort at all-the situation in Darfur has exponentially worsened. While the debate and deliberations seem to continue endlessly, Darfurians continue to die each and every day. How many 
must die-500,000? One million? Two or 3 million? - until we in the West with the means (if not the greatest will) accept our responsibility and obligation to intervene, and, if necessary, to use the hammer to stop the killings in Darfur? The time for debate is over. The time to give meaning to the cry "Never Again" is upon us.

\section{Notes}

1. Convention on the Prevention and Punishment of the Crime of Genocide, 9 December 1948, 78 U.N.T.S. 277, http://www.unhchr.ch/html/menu3/b/p_genoci.htm (accessed 21 April 2006), art. 2.

2. Ibid.

3. Ibid., art. 8 . 